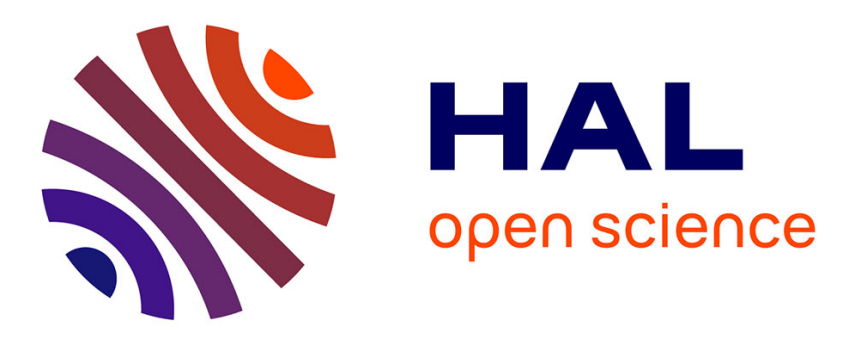

\title{
Enhanced coloration for hybrid niobium-based electrochromic devices
}

\author{
Issam Mjejri, Romain Grocassan, Aline Rougier
}

\section{To cite this version:}

Issam Mjejri, Romain Grocassan, Aline Rougier. Enhanced coloration for hybrid niobium-based electrochromic devices. ACS Applied Energy Materials, 2018, 1 (8), pp.4359-4366. 10.1021/acsaem.8b00967 . hal-01865041

\section{HAL Id: hal-01865041 \\ https://hal.science/hal-01865041}

Submitted on 30 Aug 2018

HAL is a multi-disciplinary open access archive for the deposit and dissemination of scientific research documents, whether they are published or not. The documents may come from teaching and research institutions in France or abroad, or from public or private research centers.
L'archive ouverte pluridisciplinaire HAL, est destinée au dépôt et à la diffusion de documents scientifiques de niveau recherche, publiés ou non, émanant des établissements d'enseignement et de recherche français ou étrangers, des laboratoires publics ou privés. 


\title{
Enhanced Coloration for Hybrid Niobium based Electrochromic De- vices
}

\author{
Issam Mjejri ${ }^{\dagger, \ddagger}$, Romain Grocassan ${ }^{\dagger, \ddagger}$ and Aline Rougier ${ }^{\dagger, \ddagger}, *$ \\ ${ }^{\dagger}$ CNRS, ICMCB, UMR 5026, F-33600 Pessac, France \\ ‡Univ. Bordeaux, ICMCB, UMR 5026, F-33600 Pessac, France \\ *Corresponding Author: aline.rougier@icmcb.cnrs.fr, ICMCB-CNRS, 87 avenue du Dr Albert Schweit- \\ zer, 33608 Pessac cedex, France
}

KEYWORDS. Polyol synthesis; Nanoparticles; Niobium oxide; Dip Coating; Electrochromic performances; Hybrid Device.

\begin{abstract}
Niobium pentoxide, $\mathrm{Nb}_{2} \mathrm{O}_{5}$, exists in many polymorphs with diverse properties and morphologies that are dependent on the synthesis route. In this work, we design a new approach to fabricate and stabilize the metastable polymorph hexagonal nanoniobium pentoxide using soft chemistry and in particular the polyol synthesis. The electrochromic properties of homogeneous niobium pentoxide thin films deposited by Dip Coating, from as-synthesized hexagonal powder, are studied in lithium trifluoromethanesulfonimide (LiTFSI) in 1-ethyl-3-methylimidazolium bis(trifluoromethanesulfonyl)imide (EMITFSI) ionic liquid electrolyte versus $\mathrm{Pt}$ as counter electrode. The structure and morphology of the $\mathrm{Nb}_{2} \mathrm{O}_{5}$ thin films before and after cycling are characterized by ex-situ XRD and SEM while their optical and electrochemical properties are investigated by in-situ transmittance and cyclic voltammetry (CV), respectively. Thin films made from hexagonal $\mathrm{Nb}_{2} \mathrm{O}_{5}$ with spheres architecture exhibit good cycling stability, high transmittance modulations $(\Delta \mathrm{T} \approx 33 \%$ at $550 \mathrm{~nm})$, fast switching speeds (2 to $3 \mathrm{~s}$ for coloration and bleaching at $550 \mathrm{~nm})$, and high coloration efficiency $\left(\mathrm{CE} \approx 26 \mathrm{~cm}^{2} . \mathrm{C}^{-1}\right)$ with a good quality factor $\mathrm{G}_{(\lambda)}=10.4 \mathrm{~cm}^{2} \cdot \mathrm{C}^{-1} \cdot \mathrm{s}^{-1}$. Finally, novel electrochromic devices based on hybrid thin films combining PEDOT:PSS and oxides are assembled showing enhanced coloration and simultaneous color change due to their double sided configuration.
\end{abstract}

\section{Introduction}

Currently, more than $40 \%$ of the energy consumption is in buildings either for heating or cooling, but this phenomenon is always accompanied by a rejection of carbon dioxide, $\mathrm{CO}_{2}$. To improve the energy efficiency and reduce the emission of $\mathrm{CO}_{2}$ into the atmosphere, smart windows, often based on electrochromic materials, offer a promising solution. Electrochromic (EC) materials are characterized by the ability to change their optical properties, when a voltage is applied. ${ }^{1-3}$ Electrochromism occurs in a number of organic ${ }^{4}$, inorganic ${ }^{5}$ and hybrid materials ${ }^{6}$, allowing to address multiple applications either in a transmittive mode (smart windows...) or reflective one (displays....). In comparison to others, the family of inorganic oxides is commonly known for its good stability. Another advantageous specificity lies in the facility to improve the electrochromic properties by single or double doping or by addition of other materials and formation of composites .7, 8

Since the discovery of electrochromism in $\mathrm{Nb}_{2} \mathrm{O}_{5}$ in 1980, by Reichman and $\operatorname{Bard}^{9}$, niobium oxide has been studied extensively and has come up as a promising electrochromic material in respect of chemical stability in many electrolytes, nice reversible colors switching and long-term cycling stability. ${ }^{10,}{ }^{11}$. Niobium element characterized by several valence states from +2 to +4 to +5 for $\mathrm{NbO}, \mathrm{NbO}_{2}$ and $\mathrm{Nb}_{2} \mathrm{O}_{5}$, respectively ${ }^{12}$, exists in various oxides polymorphic forms including monoclinic $(\mathrm{H}-$ $\left.\mathrm{Nb}_{2} \mathrm{O}_{5}\right)$, tetragonal $\left(\mathrm{M}-\mathrm{Nb}_{2} \mathrm{O}_{5}\right)$, orthorhombic $\left(\mathrm{T}-\mathrm{Nb}_{2} \mathrm{O}_{5}\right)$, and pseudo hexagonal $\left(\mathrm{TT}-\mathrm{Nb}_{2} \mathrm{O}_{5}\right)$. The different crystal phases of
$\mathrm{Nb}_{2} \mathrm{O}_{5}$ depend on the synthesis temperature. For example a low temperature $\left(\approx 200{ }^{\circ} \mathrm{C}\right.$ ) leads to an amorphous phase further crystallizes at $500{ }^{\circ} \mathrm{C}$ into hexagonal or orthorhombic phases, while at medium-temperature $\left(\approx 800{ }^{\circ} \mathrm{C}\right)$ niobium oxide transforms into the tetragonal phase and forms the monoclinic phase above $1000{ }^{\circ} \mathrm{C}{ }^{13,14}$. Herein, we present a novel synthesis route to stabilize the metastable phase $\left(\mathrm{TT}-\mathrm{Nb}_{2} \mathrm{O}_{5}\right)$ with ultrafine powders and we demonstrate the electrochromic performance of this metastable allotropic form of niobium pentoxide.

In the literature, a variety of approaches have been employed to fabricate $\mathrm{Nb}_{2} \mathrm{O}_{5}$ nanostructures such as hydro/solvothermal ${ }^{15}$ and sol-gel, but these methods have the inconvenience of limited reproducibility and scaling up. To solve this issue, new synthesis methods able to produce a large quantity of nanometric powders with high reactivity are highly needed. As one of the solution methods, the polyol synthesis has been initially developed for metals ${ }^{16,17}$ and more recently applied to the synthesis of single-crystalline oxide nanostructures ${ }^{18}$. This low reaction temperature method, in which the polyol serves as both the solvent and the reducing agent, offers several advantages as compared to other chemical methods. Among them a non-exhaustive list contains (i) water-comparable solubility of simple metal-salt precursors; (ii) high boiling points (up to $320^{\circ} \mathrm{C}$ ); (iii) reducing properties for the instantaneous synthesis of metals; (iv) coordinating properties for surface functionalization and colloidal stabilization of nanoparticles; (v) wide adaptability of the polyols ranging from low-weight ethylene glycol (EG) 
to high-weight polyethylene glycols (PEGs) (vi) high-quality doped powders with specific morphologies (vii) applicable to large scale manufacturing processes. In summary, this process is ideal for the processing of very fine powders having high purity, high crystallinity, excellent reproducibility, narrow particle size distribution, uniformity, and high reactivity. ${ }^{19}$

The electrochromic performance of niobium pentoxide depends on several parameters including the morphology and the porosity, the film thickness, the surface roughness and the deposition method. Various deposition techniques including spray pyrolysis $^{20}$ radio-frequency magnetron sputtering ${ }^{21}$, pulsed laser deposition ${ }^{22}$, chemical vapour deposition ${ }^{23}$ and Dip-coating techniques ${ }^{12,}{ }^{24}$ have been used to prepare $\mathrm{Nb}_{2} \mathrm{O}_{5}$ thin films. Among them, Dip Coating processes present the advantage of high versatility, low cost, reasonable deposition rates, and simplicity in experimental parameter modulation. In this study, niobium pentoxide $\left(\mathrm{Nb}_{2} \mathrm{O}_{5}\right)$ thin films were dip coated from nanopowders synthesized from a single polyol route. Herein, their electrochromic activity in lithium-based electrolyte is discussed in terms of optical contrast, cyclability, and stability. Their nice EC properties allow further integration of this oxide in complete devices optimized in respect of novel architecture and enhanced coloration.

During the recent decade, escaping from the common 5-layers battery type devices, remarkable progress have been achieved in exploring new concepts to enlarge the field of applications for electrochromic devices. Such evolution includes the development of new EC materials as well as novel architectures. For instance, in 2017 our group ${ }^{25}$ reported for the first time a double sided electrochromic device based on Metal-Organic Frameworks (MOFs). Mixing the advantages of inorganic and organic materials, hybrids systems offer great potential of exploration. Indeed, while transition metal oxide (TMOs) have generally a good redox activity with high optical properties and good memory effect, they suffer, among other things from a too low electrical conductivity. On the contrary, polymer-based electrochromic films are characterized by rapid kinetics and multicolor electrochromism, while they typically show poor adhesion to the substrate. To counter balance the pros and cons of both types of materials, we suggest mixtures of metal oxide and polymer as good candidates for electrochromic application ${ }^{26,27}$. The benefit of such approach has been recently demonstrated through various examples. Among those hybrid composite materials, mixtures of PEDOT:PSS and $\mathrm{WO}_{3}{ }^{28}$ or with $\mathrm{TiO}_{2}{ }^{29}$ are characterized by good properties. Furthermore, the combination of PEDOT:PSS and $\mathrm{V}_{2} \mathrm{O}_{5}$ in electrochromic device shows better stability as compared to a pristine PEDOT:PSS-based device ${ }^{30}$, ${ }^{31}$. Recently, Mishra and al., have shown that $\mathrm{TiO}_{2}-\mathrm{Co}_{3} \mathrm{O}_{4}$ coreshell has a good electrochromic behavior and superior supercapacitive poroperties. ${ }^{32}$ In the same context, Zhang and al., reported that the organic-inorganic nanocomposites $\left(\mathrm{ATO} / \mathrm{TiO}_{2} @ \mathrm{PANI}\right)^{33}$ present better electrochromic performance compared with pure PANI film. According to the authors the improved electrochromic properties are mainly attributed to the core/shell structure, formation of the donor-acceptor system. Based on this finding, we successfully combine two hybrids films (namely $\mathrm{Nb}_{2} \mathrm{O}_{5}$ - PEDOT:PSS and $\mathrm{V}_{2} \mathrm{O}_{5}-$ PEDOT:PSS ) to build for the first time a hybrid electrochromic device with dual face.

\section{Experimental details \\ II.1. Polyol synthesis of $\mathrm{Nb}_{2} \mathrm{O}_{5}$ powder and characteriza- tion}

All of the chemical reagents were purchased from Acros Organics and utilized without further purification. Ammonium niobate (V) oxalate hydrate was used as niobium source and diethylene glycol (DEG) as template. In a typical synthesis, $\mathrm{C}_{4} \mathrm{H}_{4} \mathrm{NNbO}_{9} . \mathrm{H}_{2} \mathrm{O}$ (7.574 g) was added to $250 \mathrm{~mL}$ of $\mathrm{C}_{4} \mathrm{H}_{10} \mathrm{O}_{3}$. The resulting mixture was heated to $110^{\circ} \mathrm{C}$ with continuous stirring to give a white solution that was refluxed at $160^{\circ} \mathrm{C}$ for $1 \mathrm{~h}$. At the end of the reaction, a white precipitate was obtained. The precipitate was centrifuged and washed several times with ethanol to remove the organic product and dried in an oven at $80{ }^{\circ} \mathrm{C}$. To prepare the final $\mathrm{Nb}_{2} \mathrm{O}_{5}$ powders, the precipitates were calcined for $1 \mathrm{~h}$ at $500^{\circ} \mathrm{C}$.

The powder structure was characterized by X-ray diffraction analysis (Philips PW 1820, PANalyticalX'Pert instrument, $2 \theta$ range from 15 to $60^{\circ}$ and $\left.\lambda_{\mathrm{CuK} \alpha 1}=0.154056 \mathrm{~nm}\right)$. The unit cell parameters were refined by structural pattern matching using the Fullprof program package. Transmission electron microscopy (TEM) images were recorded with a SEI instrument (operating at $5 \mathrm{kV}$ ) microscope.

\section{II.2. Film preparation and characterization}

$\mathrm{Nb}_{2} \mathrm{O}_{5}$ films were deposited by the dip coating method from homemade powder, synthesized by the polyol process. Firstly, $2.5 \mathrm{~g}$ of powder was dispersed into $5 \mathrm{ml}$ ethanol. The resulting dilute was stirred for $1 \mathrm{~h}$ at room temperature and after aliquots of the as-prepared colloidal $\mathrm{Nb}_{2} \mathrm{O}_{5}$ solution were deposited on the ITO $\left(\mathrm{In}_{2} \mathrm{O}_{3}: \mathrm{Sn}\right.$ ) coated glass (ccommercialized by SOLEM with a resistance of $30 \Omega / \square$ ). The thickness of the $\mathrm{Nb}_{2} \mathrm{O}_{5}$ films, measured using a Dektak mechanical profilometer, was of about $800 \mathrm{~nm} \pm 50 \mathrm{~nm}$. For the identification of the crystal phases of the thin films before and after cycling, X-ray diffraction (XRD, Philips PW 1820, PANalyticalX'Pert instrument, $2 \theta$ range from 15 to $60^{\circ}$ and $\lambda_{\text {CuKal }}=0.154056 \mathrm{~nm}$ ) was used.

The morphology of the layers before and after cycling was investigated using a JEOL JSM-840 (operating at $15 \mathrm{kV}$ ) microscope.

\section{II.3. Electrochromic measurements}

Electrochemical measurements of $\mathrm{Nb}_{2} \mathrm{O}_{5}$ thin films on ITO/glass were carried out in a three electrodes cell configuration using a BioLogic SP50 potentiostat/galvanostat apparatus. The counter-electrode and reference electrode consisted of a platinum foil and Saturated Calomel Electrode, SCE $\left(\mathrm{E}_{\mathrm{SCE}}=\right.$ $0.234 \mathrm{~V} / \mathrm{ENH}$ ), respectively. The operating voltage was controlled between -1.1 and $-0.1 \mathrm{~V}$ at a scan rate of $20 \mathrm{mV} / \mathrm{s}$, in lithium based electrolyte, namely, lithium bis-trifluoromethanesulfonimide (LiTFSI, Solvionic, purityN99.99\%) in 1etyl-3-methylimidazoliumbis-(trifluoromethanesulfonyl)-im-

ide (EMITFSI), purity N 99.99\%). All the electrochemical measurements were performed at room temperature. The optical transmittance of $\mathrm{Nb}_{2} \mathrm{O}_{5}$ thin films was measured in-situ using a Varian Cary 5000 UV-Vis-NIR spectrophotometer.

\section{Results and discussion}

\section{III.1. Polyol synthesis of $\mathrm{Nb}_{2} \mathrm{O}_{5}$ powder}

The crystallinity of the powder synthesized by the polyol process pre- and post-calcined under air was analyzed by XRD (Figure 1). Prior to calcination, the XRD pattern (Figure 1a), with no visible peaks, corresponds to an amorphous phase, in agreement with R.A. Rani et al. ${ }^{14}$, reporting amorphous $\mathrm{Nb}_{2} \mathrm{O}_{5}$ at low temperature $\left(\approx 200{ }^{\circ} \mathrm{C}\right)$. As the temperature of the calcination increases, niobium oxide becomes crystallized. At 400 
${ }^{\circ} \mathrm{C}$, (Figure 1b), the XRD pattern reveals the presence of a predominantly amorphous phase with the appearance of a single peak characteristic of the hexagonal phase of $\mathrm{Nb}_{2} \mathrm{O}_{5}$. An increase in temperature to $500{ }^{\circ} \mathrm{C}$ (Figure 1c) leads to a well crystallized phase with narrow X-ray peaks. The d-spacing values of all diffraction peaks are identical to those of the hexagonal crystalline phase $\mathrm{Nb}_{2} \mathrm{O}_{5}$ with lattice constants $\mathrm{a}=\mathrm{b}=3.6070 \AA$, and $\mathrm{c}=3.9250 \AA$ (JCPDS \# 28-0317). The absence of any additional peaks from other phase or impurity indicates that $\mathrm{Nb}_{2} \mathrm{O}_{5}$ with high purity can be synthesized via the polyol synthesis at $160{ }^{\circ} \mathrm{C}$ for $1 \mathrm{~h}$. The hexagonal phase remains predominant after a post-thermal treatment at $600{ }^{\circ} \mathrm{C}$ (Figure 1d) with the appearance of some small peaks characteristic of orthorhombic $\mathrm{Nb}_{2} \mathrm{O}_{5}$.

From the temperature study, a treatment of the powders obtained by polyol process at $500{ }^{\circ} \mathrm{C}$ for $2 \mathrm{~h}$ under air was established as optimal conditions to synthesize the metastable $\mathrm{Nb}_{2} \mathrm{O}_{5}$ hexagonal phase with high crystallinity chosen for further investigation.

The average crystallite size was calculated using the Scherrer's formula:

$$
L=0.89 \lambda=\beta \cos \theta
$$

Where $\mathrm{L}$ is the average crystallite size in $\mathrm{nm}, \lambda=0.154056 \mathrm{~nm}$, $\beta$ is the full width at the half maximum, and $\theta$ is the diffraction angle. The average crystallite size value, calculated from three of the main peaks of the XRD pattern, is about $9 \mathrm{~nm}$.

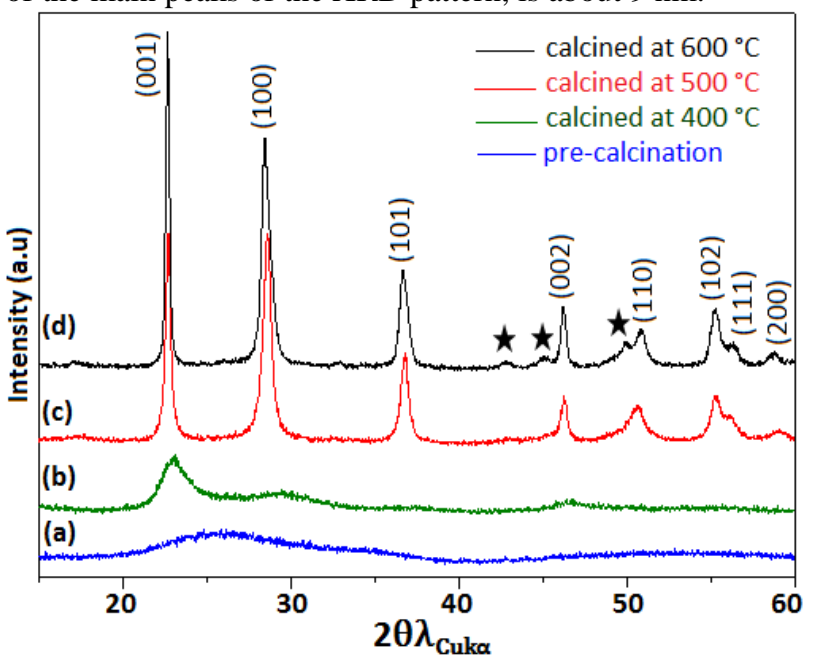

FIGURE 1. XRD patterns of the niobium oxide powders synthesized by polyol process (a) pre-calcination and post-calcination at (b) $400{ }^{\circ} \mathrm{C}$, (c) $500{ }^{\circ} \mathrm{C}$ and (d) $600{ }^{\circ} \mathrm{C}$ under air for $2 \mathrm{~h}$. ( correspond to orthorhombic $\mathrm{Nb}_{2} \mathrm{O}_{5}$.

Figure 2 shows the corresponding TEM images of the powders elaborated by the polyol process. The hexagonal $\mathrm{Nb}_{2} \mathrm{O}_{5}$ phase is homogenous with particles regularly sized and which display 2D nanospheres morphology, with a radius ranging from $10 \mathrm{~nm}$ to $35 \mathrm{~nm}$.

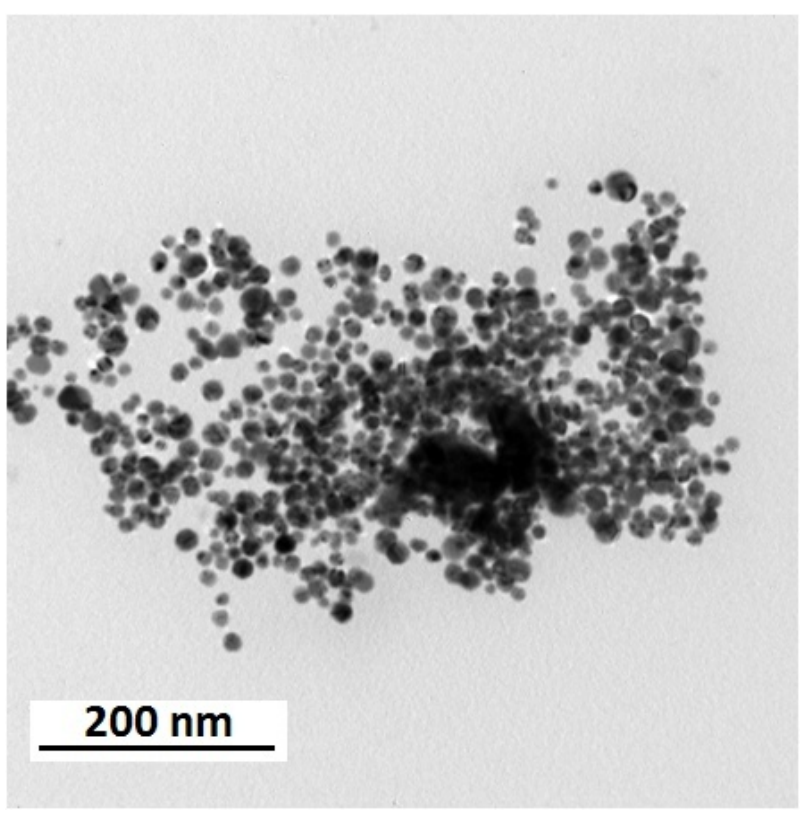

FIGURE 2. TEM images of hexagonal $\mathrm{Nb}_{2} \mathrm{O}_{5}$ powder after thermal treatment at $500{ }^{\circ} \mathrm{C}$ for $2 \mathrm{~h}$ under air.

To complete the structural studies, refinement using an isotropic peak profile function (Caglioti function) was carried out on the hexagonal $\mathrm{Nb}_{2} \mathrm{O}_{5}$ compound (Figure S1). Unit-cells parameters and the reliability factors $\left(R_{p}, R_{w p}\right.$, and $\left.R_{\exp }\right)$ are summarized in Table S1. The isotropy of the structure well agrees with the isotropy of the morphology.

\section{III.2. Electrochromic properties of $\mathrm{Nb}_{2} \mathrm{O}_{5}$ thin films}

\section{III.2.1. Cyclic voltammetry (CV) measurements}

An important requirement of electrochromic materials is their stability upon cycling while keeping their structural integrity. The repetitive cycling of $\mathrm{Nb}_{2} \mathrm{O}_{5}$ thin film in LiTFSI-EMITFSI ionic liquid at a scan rate of $20 \mathrm{mV} / \mathrm{s}$ between $-1.1 \mathrm{~V}$ as $-0.1 \mathrm{~V}$ shows good reversibility and cyclability (Figure 3a and inset Figure 3a). No significant degradation corresponding to only 1 $\%$ decrease of the capacity after 100 cycles (inset Figure 3a) confirms this good stability. Upon cathodic and anodic sweeping, the transparent films show one-step electrochromism from transparent to blue (Figure $\mathbf{3 b}$ ). The color change is accompanied by the appearance of a well-defined oxidation peak located at $-0.63 V$. During the cathodic scan a simultaneous insertion of electrons and $\mathrm{Li}^{+}$ions into the $\mathrm{Nb}_{2} \mathrm{O}_{5}$ film causes the reduction of $\mathrm{Nb}^{5+}$ to lower valence state, $\mathrm{Nb}^{4+}$ and hence the film coloration. In its reduced state, the film appears blue. During the anodic scan, the deinsertion of $\mathrm{Li}^{+}$ions causes the bleaching of the film that becomes transparent. As reported in the literature ${ }^{24,34}$, the redox chemical reaction associated with coloration and bleaching in $\mathrm{Nb}_{2} \mathrm{O}_{5}$ films can be schematized as follows:

$$
\mathrm{Nb}_{2} \mathrm{O}_{5}+\mathrm{xe}^{-}+\mathrm{xLi}^{+} \longleftrightarrow \mathrm{Li}_{\mathrm{x}} \mathrm{Nb}_{2} \mathrm{O}_{5}
$$

The number of exchanged $\mathrm{Li}^{+}(\mathrm{x})$ involved during each coloration/bleaching process was estimated using the following equation: $\mathrm{Q}=\mathrm{F}^{*} \mathrm{n}\left(\mathrm{Nb}_{2} \mathrm{O}_{5}\right)^{*} \mathrm{x}$, where $\mathrm{Q}$ is the electrochemical capacity, $\mathrm{F}=96500 \mathrm{C}$, and $\mathrm{n}$ is number of moles. Assuming a density close to $100 \%$, $\mathrm{x}$ value of about 2 was calculated suggesting the participation of all $\mathrm{Nb}$ ions in the $\mathrm{Nb}^{5+}$ to $\mathrm{Nb}^{4+}$ redox process. 
After 100 cycles, negligible shift in the position of the oxidation peaks was observed. The origin of such deviation remains unclear but might be ascribed to a modification of the film morphology upon cycling.
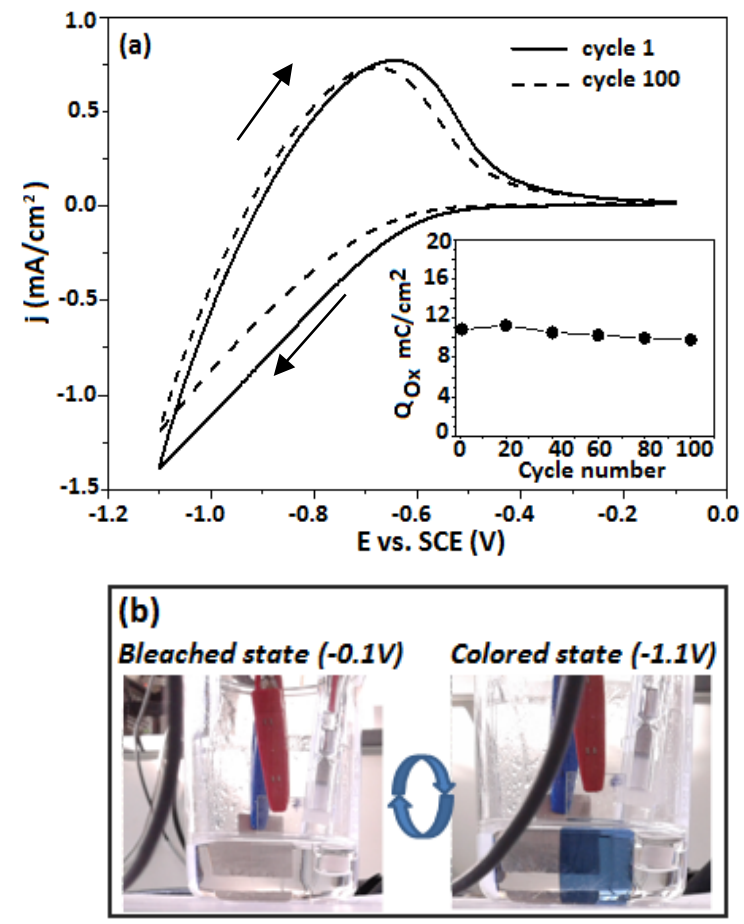

FIGURE 3 . The $1^{\text {st }}$ and the $100^{\text {th }}$ cyclic voltammograms for the $\mathrm{Nb}_{2} \mathrm{O}_{5} / \mathrm{LiTFSI}$ in EMITFSI/Pt/SCE recorded at $20 \mathrm{mV} / \mathrm{s}$ scan rate (a), Corresponding variation of the anodic capacity upon cycling (inset Fig. 3a) and Visual appearance of $\mathrm{Nb}_{2} \mathrm{O}_{5}$ films in the bleached and colored states (b).

\section{III.2.2. Optical properties}

The in-situ transmittance upon cycling of $\mathrm{Nb}_{2} \mathrm{O}_{5} / \mathrm{LiTFSI}$ in EMITFSI/Pt/SCE is displayed in Figure 4. The colored-blue state $(-1.1 \mathrm{~V})$ and the bleached-transparent state at $(-0.1 \mathrm{~V})$ are associated with transmittance values of about $\mathrm{T}_{\mathrm{c}} \approx 55 \%$ and $\mathrm{T}_{\mathrm{b}}$ $\approx 88 \%$ at $550 \mathrm{~nm}$, respectively, corresponding to a total optical transmittance modulation of $\Delta \mathrm{T} \approx 33 \%$. The electrochromic performance is commonly characterized by the optical density (OD) represented by the logarithmic ratio of the transmittance in the bleached state $\left(\mathrm{T}_{\mathrm{b}}\right)$ to the transmittance in colored state $\left(\mathrm{T}_{\mathrm{c}}\right)$ and the coloration efficiency (CE) defined as the change in optical density per unit-inserted charge. The $\triangle \mathrm{OD}$ and coloration efficiency (CE) are calculated using the two relations:

$$
\Delta \mathrm{OD}=\log \left(\mathrm{T}_{\mathrm{b}} / \mathrm{T}_{\mathrm{c}}\right)
$$

Where, $\mathrm{T}_{\mathrm{b}}$ and $\mathrm{T}_{\mathrm{c}}$ are the transmittance of the $\mathrm{Nb}_{2} \mathrm{O}_{5}$ film in the bleached and colored states, respectively.

$$
\mathrm{CE}=\Delta \mathrm{OD} / \mathrm{Q}
$$

Where, Q is the amount of charge transferred per unit area. From calculated optical density $(\Delta \mathrm{OD}=0.205)$ and the amount of charge $\left(\mathrm{Q}=0.008 \mathrm{C} / \mathrm{cm}^{2}\right)$, a coloration efficiency $26 \mathrm{~cm}^{2} / \mathrm{C}$ is obtained. Such values nicely compared with values reported in the literature ${ }^{34,35}$ (Table 1).
The switching optical response in between alternating potentials is a key characteristic of electrochromic materials. The switching kinetics of $\mathrm{Nb}_{2} \mathrm{O}_{5}$ thin film was deduced from monitoring the transmittance at a wavelength of $550 \mathrm{~nm}$ under the application of potentials window of $-1.1 \mathrm{~V}$ and $-0.1 \mathrm{~V}$ at 10 $\mathrm{mV} / \mathrm{s}$. The response times, slightly higher in the bleaching process (3s) than in the colored one (2s), due probably to the transition from the semiconductor $\left(\mathrm{Nb}_{2} \mathrm{O}_{5}\right)$ to conductor $\left(\mathrm{Li}_{\mathrm{x}} \mathrm{Nb}_{2} \mathrm{O}_{5}\right)$ while the process is faster from a conductive to a semi-conductive behavior, remain of few seconds.

To appraise the overall EC performances of the $\mathrm{Nb}_{2} \mathrm{O}_{5}$ films, we calculated a quality factor $\mathrm{G}_{(\lambda)}$ using the relation: ${ }^{36}$

$\mathrm{G}_{(\lambda)}=\mathrm{CE}_{(\lambda)} / \boldsymbol{\tau}, \boldsymbol{\tau}=\left(\boldsymbol{\tau}_{\mathrm{c}}+\boldsymbol{\tau}_{\mathrm{b}}\right) / 2$

The value of $\mathrm{G}(550 \mathrm{~nm})$ for a $\mathrm{Nb}_{2} \mathrm{O}_{5}$ thin films is $10.4 \mathrm{~cm}^{2} . \mathrm{C}^{-1}$ . $\mathrm{s}^{-1}$. This value, not reported in the literature to our knowledge for $\mathrm{Nb}_{2} \mathrm{O}_{5}$, is 2.54 times as high as the one of typical electrochromic oxide $\mathrm{WO}_{3}{ }^{36}$.

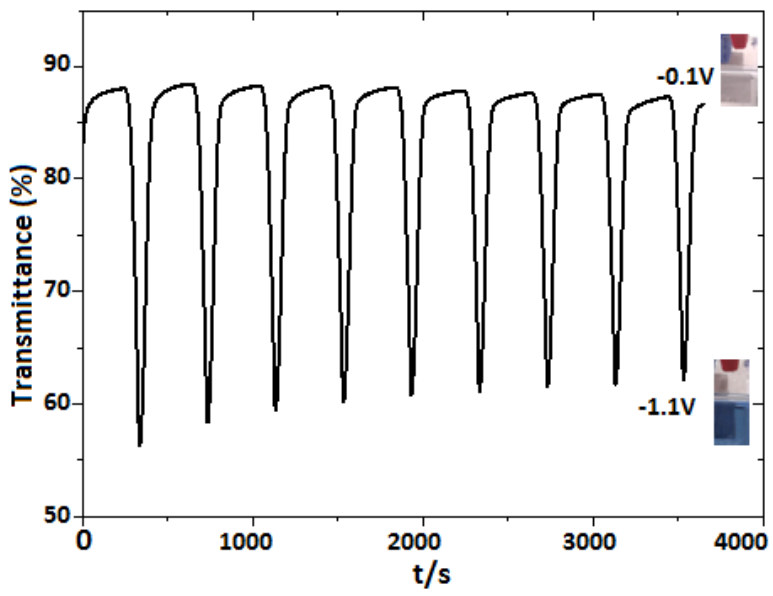

FIGURE 4. Transmittance curves of the $\mathrm{Nb}_{2} \mathrm{O}_{5} / \mathrm{LiTFSI}$ in EMITFSI/Pt/SCE recorded in situ at $550 \mathrm{~nm}$ with voltammetry cyclic range $-1.1 \mathrm{~V}$ to $-0.1 \mathrm{~V}$.

In summary, the comparison of the electrochromic characteristic of $\mathrm{Nb}_{2} \mathrm{O}_{5}$ thin films with the ones reported in the literature confirm the benefit of the polyol synthesis which leads to very fine and very reactive powder showing higher performances (Table 1).

TABLE 1. Comparison of the electrochromic performance of $\mathrm{Nb}_{2} \mathrm{O}_{5}$ thin films with literature.

\begin{tabular}{llllc}
\hline Ref. & $\Delta \mathrm{T}(\%)$ & $\mathrm{CE}\left(\mathrm{cm}^{2} . \mathrm{C}^{-1}\right)$ & $\mathrm{t}_{\mathrm{c}}(\mathrm{s})$ & $\mathrm{tb}(\mathrm{s})$ \\
\hline $\mathrm{Nb}_{2} \mathrm{O}_{5}{ }^{[37]}$ & 25.4 & 4.63 & --- & --- \\
$\mathrm{Nb}_{2} \mathrm{O}_{5}{ }^{[35]}$ & ---- & 13 & 3.7 & 4.7 \\
$\mathrm{Nb}_{2} \mathrm{O}_{5}{ }^{[24]}$ & ---- & 22 & --- & --- \\
$\mathrm{Nb}_{2} \mathrm{O}_{5}{ }^{[21]}$ & ---- & 10 & -- & --- \\
$\mathrm{Nb}_{2} \mathrm{O}_{5}$ in & 33 & 26 & 2 & 3 \\
this work & & & & \\
\hline
\end{tabular}


III.3. Structure and morphology of the $\mathrm{Nb}_{2} \mathrm{O}_{5}$ films before and after cycling

The XRD pattern of the $\mathrm{Nb}_{2} \mathrm{O}_{5}$ film deposited by Dip-Coating is shown in Figure 5a. The d-spacing values of all diffraction peaks match the ones of the hexagonal crystalline phase (JCPDS\# 007-0061) and of the ITO substrate (JCPDS \# 441087). No major change in XRD peak position compared to $\mathrm{Nb}_{2} \mathrm{O}_{5}$ powders and no peaks of any other phase or impurity are detected after deposition on ITO substrate, demonstrating a good stability of $\mathrm{Nb}_{2} \mathrm{O}_{5}$ nanoparticles synthesized by the polyol method using these deposition conditions. Figure $\mathbf{5 b}$ and $\mathbf{5 c}$ shows the XRD of the $\mathrm{Nb}_{2} \mathrm{O}_{5}$ film in reduced and oxidized state, after 50 cycles. All peaks are indexed to the crystal phase of hexagonal $\mathrm{Nb}_{2} \mathrm{O}_{5}$ indicating a remarkable stability upon repeated lithium insertion and deinsertion. A close examination of the XRD patterns upon cycling reveals an increase in the width at half height with cycling while in the reduced state the slight shift of the peaks towards low theta values well agrees with an insertion of lithium and the formation of $\mathrm{Li}_{x} \mathrm{Nb}_{2} \mathrm{O}_{5}$ (Figure S2). The crystallite size, calculated using the Scherrer formula, for the $\mathrm{Nb}_{2} \mathrm{O}_{5}$ film as deposited and reduced/oxidized $\mathrm{Nb}_{2} \mathrm{O}_{5}$ film after 50 cycles is about 30, 20 and $15 \mathrm{~nm}$, respectively.

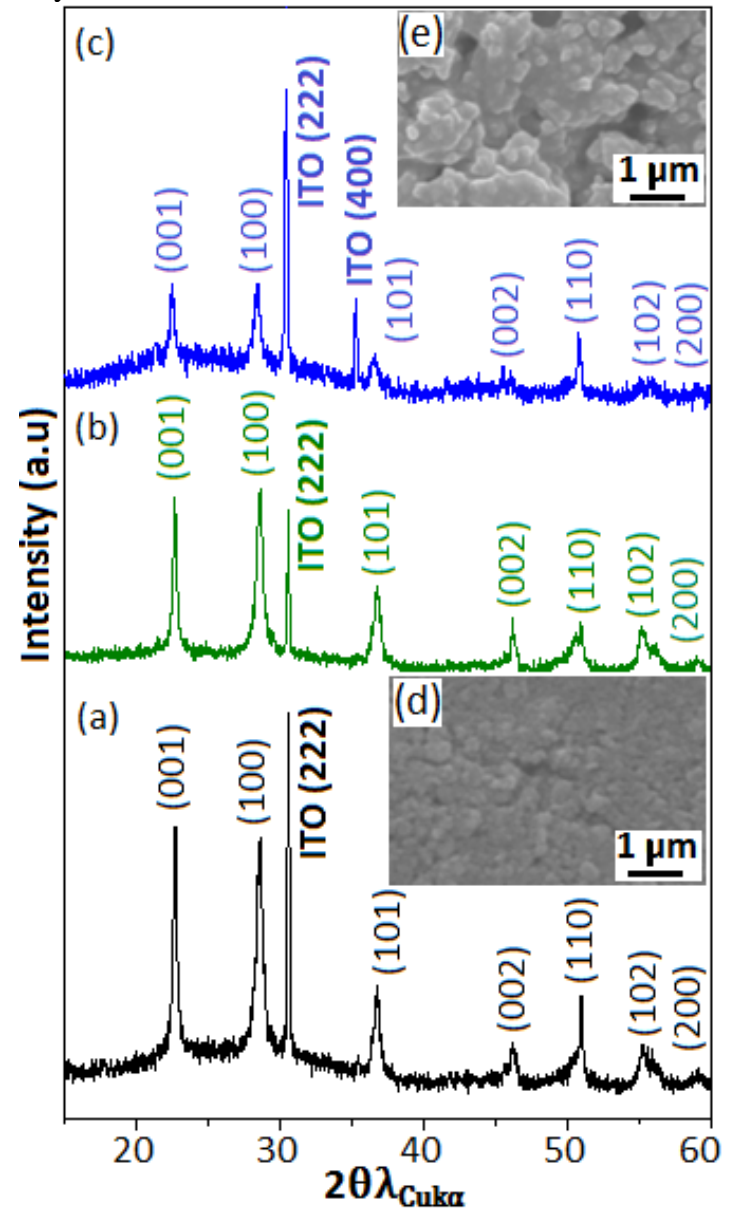

FIGURE 5. XRD patterns of (a) $\mathrm{Nb}_{2} \mathrm{O}_{5}$ film as-deposited on ITO/glass substrate (b) ex-situ XRD patterns of the reduced $\mathrm{Li}_{\mathrm{x}} \mathrm{Nb}_{2} \mathrm{O}_{5}$ film and (c) ex-situ XRD patterns of the oxidized $\mathrm{Nb}_{2} \mathrm{O}_{5}$ film after the $50^{\text {th }}$ cycle. SEM images of (d) $\mathrm{Nb}_{2} \mathrm{O}_{5}$ film as-deposited on ITO/glass substrate and (e) ex-situ SEM images of the oxidized $\mathrm{Nb}_{2} \mathrm{O}_{5}$ film after the $50^{\text {th }}$ cycle.
The SEM analysis of the $\mathrm{Nb}_{2} \mathrm{O}_{5}$ film before cycling (Figure 5d) shows that the Dip Coating deposition leads to homogeneous films of uniform particles with smooth surfaces being relatively densely covered and containing many small cracks. Such morphology, exhibiting a large surface exchange with the electrolytes, appears well suitable for the alkaline elements insertion. SEM imaging of the $\mathrm{Nb}_{2} \mathrm{O}_{5}$ film after 50 cycles (Figure 5e) shows a significant change in the morphology. After cycling, the morphology of $\mathrm{Nb}_{2} \mathrm{O}_{5}$ film consists of an assortment of small particles that agglomerated giving places to large particles of indefinite forms. Besides the presence of visible voids indicates that upon cycling the electrolyte penetration may be progressively facilitate, promoting the insertion/deinsertion of lithium ions in the $\mathrm{Nb}_{2} \mathrm{O}_{5}$ matrix.

\section{III.4. Hybrid Electrochromic Devices}

III.4.1. Fabrication of hybrid electrochromic Device

Using the common 5-layer type battery device, an electrochromic device consisting of two hybrid electrochromic films separated by an electrolyte was assembled. $\mathrm{V}_{2} \mathrm{O}_{5} /$ PEDOT:PSS and $\mathrm{Nb}_{2} \mathrm{O}_{5} / \mathrm{PEDOT}$ :PSS have been employed as the two electrodes and the $60 \%$ of (LiTFSI-BMTFSI blended with PMMA) and $40 \%$ of $\mathrm{TiO}_{2}$ (Sigma Aldrich) is used as the electrolyte membrane. The same protocol was utilized to prepared both (Oxide/PEDOT:PSS) electrodes. $70 \%$ of oxide nanopowders $\left(\mathrm{Nb}_{2} \mathrm{O}_{5}\right.$ or $\left.\mathrm{V}_{2} \mathrm{O}_{5}\right)$ synthesized by polyol process were mixed with 30\% PEDOT:PSS (Sigma Aldrich) in ethanol as solvent (this mass ratio between oxides and PEDOT:PSS was optimized to get the highest contrast in the visible) and then the mixture was stirred for $3 \mathrm{~h}$. After the preparation of the suspension, the dip coating method was used to deposit the $\mathrm{Nb}_{2} \mathrm{O}_{5}$ (or $\mathrm{V}_{2} \mathrm{O}_{5}$ )/PEDOT:PSS layer on ITO. The two hybrids films were dried in air at room temperature. The ionic electrolyte membrane was prepared by mixing $60 \%$ of (LiTFSI-BMTFSI blended with PMMA) and $40 \%$ of $\mathrm{TiO}_{2}$ and then the mixture was stirred for $12 \mathrm{~h}$ (Figure S3).

The hybrid composite $\left[\mathrm{Nb}_{2} \mathrm{O}_{5}+\mathrm{PEDOT}\right.$ :PSS] film was cycled in the LiTFSI-EMITFSI electrolyte for five cycles and assembled in the blue reduced state to the precycled orange hybrid composite film $\left[\mathrm{V}_{2} \mathrm{O}_{5}+\right.$ PEDOT:PSS].

III.4.2. Electrochromic performance of the hybrid Device Figure 6a shows the superposition of the CVs for the two types of devices: (i) inorganic device $\mathrm{Li}_{\mathrm{x}} \mathrm{Nb}_{2} \mathrm{O}_{5}$ /electrolyte $/ \mathrm{V}_{2} \mathrm{O}_{5}$ and (ii) hybrid

device $\mathrm{Li}_{\mathrm{x}}\left[\mathrm{Nb}_{2} \mathrm{O}_{5}+\mathrm{PEDOT}\right.$ :PSS/electrolyte/ $\mathrm{V}_{2} \mathrm{O}_{5}+\mathrm{PEDOT}$ :PSS $]$ cycled at room temperature in ionic liquid at $10 \mathrm{mV} / \mathrm{s}$. The combination of both cyclic voltammetry as well as in-situ reflectance shows higher electroactivity for the hybrid device associated with higher optical contrast. Indeed, the modulation in reflectance of the hybrid device is quite double the one of the inorganic ECD $(\Delta \mathrm{R}=21 \%$ for inorganic ECD $<<42 \%$ for hybrid ECD) (Figure 6b). In the following, we focus our attention on the hybrid device. 

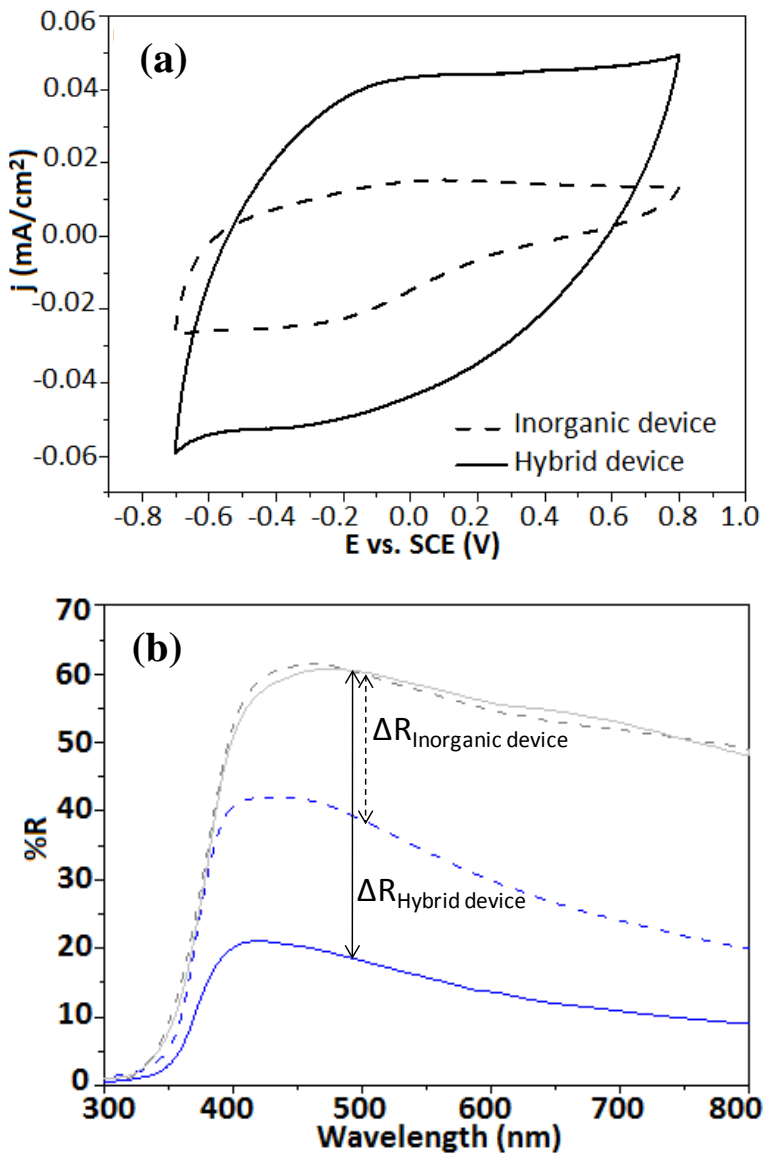

FIGURE 6. Comparaison of (a) cyclic voltammograms of the inorganic device $\left(\mathrm{Li}_{x} \mathrm{Nb}_{2} \mathrm{O}_{5} /\right.$ electrolyte/ $\left./ \mathrm{V}_{2} \mathrm{O}_{5}\right)$ and hybrid device ( $\mathrm{Li}_{\mathrm{x}}\left[\mathrm{Nb}_{2} \mathrm{O}_{5}+\mathrm{PEDOT}: \mathrm{PSS}\right] /$ electrolyte/[ $\left.\left.\mathrm{V}_{2} \mathrm{O}_{5}+\mathrm{PEDOT}: \mathrm{PSS}\right]\right), \quad$ (b) the in-situ modulation reflectance of the inorganic device $\left(\mathrm{Li}_{\mathrm{x}} \mathrm{Nb}_{2} \mathrm{O}_{5}\right.$ /electrolyte/ $\left.\mathrm{V}_{2} \mathrm{O}_{5}\right)$ and hybrid device ( $\mathrm{Li}_{x}\left[\mathrm{Nb}_{2} \mathrm{O}_{5}+\mathrm{PEDOT}: \mathrm{PSS}\right] /$ electrolyte/[ $\left.\mathrm{V}_{2} \mathrm{O}_{5}+\mathrm{PEDOT}: \mathrm{PSS}\right]$ ).

The cyclic voltammogramms (CVs) of the $\left(\mathrm{Li}_{\mathrm{x}}\left[\mathrm{Nb}_{2} \mathrm{O}_{5}+\right.\right.$ PEDOT:PSS]/electrolyte/[ $\mathrm{V}_{2} \mathrm{O}_{5}+$ PEDOT:PSS]) taken between $-0.7 \mathrm{~V}$ and $0.8 \mathrm{~V}$, at a cycling rate of $10 \mathrm{mV} \mathrm{s}^{-1}$ (Figure 7a) illustrates a well reversible behavior with good cyclability associated with nice color switches which differ on the two faces. $\mathrm{Nb}_{2} \mathrm{O}_{5}+$ PEDOT:PSS reversibly changed from bluewhite to dark-blue and $\mathrm{V}_{2} \mathrm{O}_{5}+\mathrm{PEDOT}$ :PSS from orange to blue/green (Figure 7b).
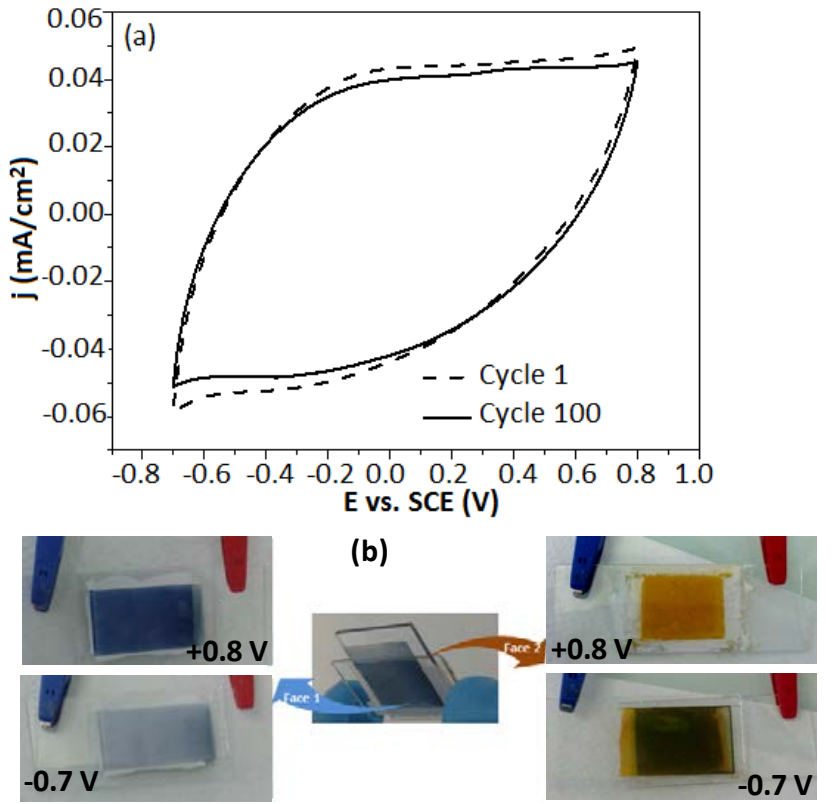

FIGURE 7. Cyclic voltammograms of the ITO/ $\mathrm{Li}_{x}\left[\mathrm{Nb}_{2} \mathrm{O}_{5}+\right.$ PEDOT:PSS]/electrolyte/[ $\mathrm{V}_{2} \mathrm{O}_{5}+\mathrm{PEDOT}$ :PSS]/ITO hybrid device between -0.7 and $0.8 \mathrm{~V}$ with a $10 \mathrm{mV} / \mathrm{s}$ scan rate for 100 cycles (a). Schematic of ITO/ $/ \mathrm{Li}_{x}\left[\mathrm{Nb}_{2} \mathrm{O}_{5}\right.$ +PEDOT:PSS]/electrolyte/[ $\mathrm{V}_{2} \mathrm{O}_{5}+$ PEDOT:PSS]/ITO electrochromic device combining $\mathrm{Li}_{\mathrm{x}}\left[\mathrm{Nb}_{2} \mathrm{O}_{5}+\mathrm{PEDOT}: \mathrm{PSS}\right]$ and $\mathrm{V}_{2} \mathrm{O}_{5}+$ PEDOT:PSS films on ITO substrates separated by an electrolyte membrane consisting of LiTFSI-BMITFSI mixture with $\mathrm{TiO}_{2}$ and blended with PMMA (b).

The switching kinetics of the hybrid device was investigated by chronoamperometric (CA) measurements. Figure 8 shows current transient $(\mathrm{j}-\mathrm{t})$ for the ITO/ $\mathrm{Nb}_{2} \mathrm{O}_{5}+\mathrm{PEDOT}$ :PSS/LiTFSIEMITFSI+ $\mathrm{TiO}_{2}$ in PMMA $/ \mathrm{V}_{2} \mathrm{O}_{5}+\mathrm{PEDOT}$ :PSS/ITO for potential steps of $(+1 \mathrm{~V} / 30 \mathrm{~s})$ and $(-1 \mathrm{~V} / 30 \mathrm{~s})$. Both response times are in the order of a few seconds; $3 \mathrm{~s}$ for the oxidation and $2 \mathrm{~s}$ for the reduction.

The optical contrasts of the two faces were evaluated using the $\mathrm{L}^{*} \mathrm{a} * \mathrm{~b} *$ color system. In fact, in CIE colorimetric space, the color is represented by three parameters: a luminance axis $\left(\mathrm{L}^{*}\right)$ and two hue axes $\left(a^{*}\right)$ and $\left(b^{*}\right)$, which can be used to define and compare quantitatively the colors. The optical contrast $\Delta \mathrm{E}^{*}$ is defined by this equation:

$\Delta \mathrm{E}^{*}=\left[\left(\mathrm{L}^{*}{ }_{\mathrm{c}}-\mathrm{L}^{*}{ }_{\mathrm{b}}\right)^{2}+\left(\mathrm{a}^{*}{ }_{\mathrm{c}}-\mathrm{a}^{*}{ }_{\mathrm{b}}\right)^{2}+\left(\mathrm{b}^{*}{ }_{\mathrm{c}}-\mathrm{b}^{*}{ }_{\mathrm{b}}\right)^{2}\right]^{1 / 2}$

For both sides $\mathrm{Nb}_{2} \mathrm{O}_{5}+$ PEDOT:PSS switch from white-blue to dark-blue, and $\mathrm{V}_{2} \mathrm{O}_{5}$ /PEDOT:PSS, from orange to green-blue, are in the order of 55 and 46, respectively. 


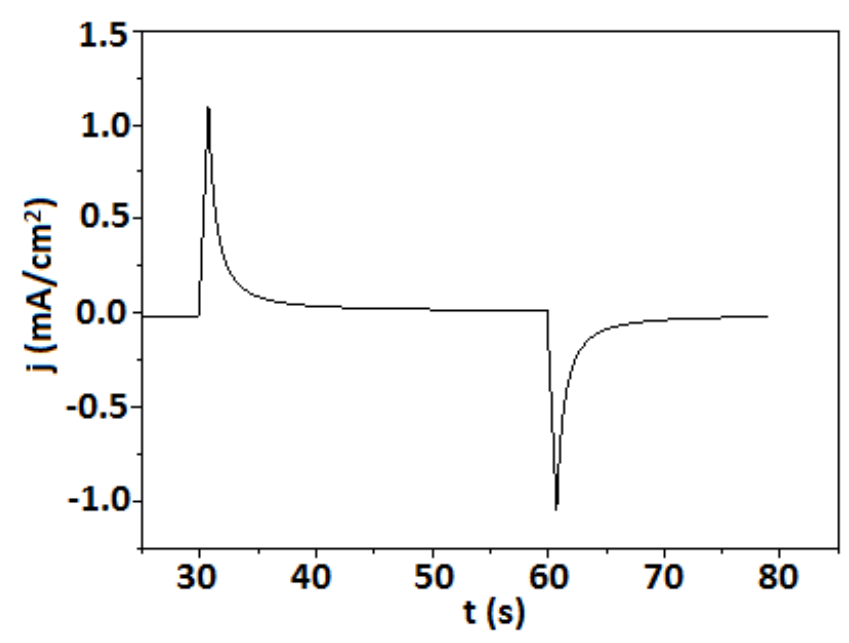

FIGURE 8. Chronoamperogramms of $\mathrm{Li}_{x}\left[\mathrm{Nb}_{2} \mathrm{O}_{5}+\right.$ PEDOT: PSS]/electrolyte/[ $\mathrm{V}_{2} \mathrm{O}_{5}+\mathrm{PEDOT}$ : PSS] device at $-1 \mathrm{~V}$ for $30 \mathrm{~s}$ and $1 \mathrm{~V}$ for $30 \mathrm{~s}$.

Figure 9 shows the in-situ optical reflectance spectra for the bleached and colored states from the double sided hybrid EC device at wavelengths ranging from 300 to $800 \mathrm{~nm}$. The reduced blue-white state $(-1 \mathrm{~V} / 30 \mathrm{~s})$ and the oxidized dark blue state $(+1$ V/30 s) (Figure 9a) are associated with reflectance values of about $\mathrm{R}_{\mathrm{R}} \approx 16 \%$ and $\mathrm{R}_{\mathrm{O}} \approx 60 \%$ at $550 \mathrm{~nm}$, respectively, corresponding to a reflectance modulation $\Delta \mathrm{R}$ of $44 \%$. The in-situ evolution of the reflectance spectra for the second hybrid face $\left(\mathrm{V}_{2} \mathrm{O}_{5}+\mathrm{PEDOT}\right.$ :PSS) is depicted in (Figure 9b). The reducedgreen state $(-1 \mathrm{~V} / 30 \mathrm{~s})$ and the oxidized-orange state at $(+1 / 30$ s) are associated with reflectance values of about $\mathrm{R}_{\mathrm{R}} \approx 3 \%$ and $\mathrm{R}_{\mathrm{O}} \approx 26 \%$ at $550 \mathrm{~nm}$, respectively, with a total reflectance modulation of $\Delta \mathrm{R} \approx 23 \%$.
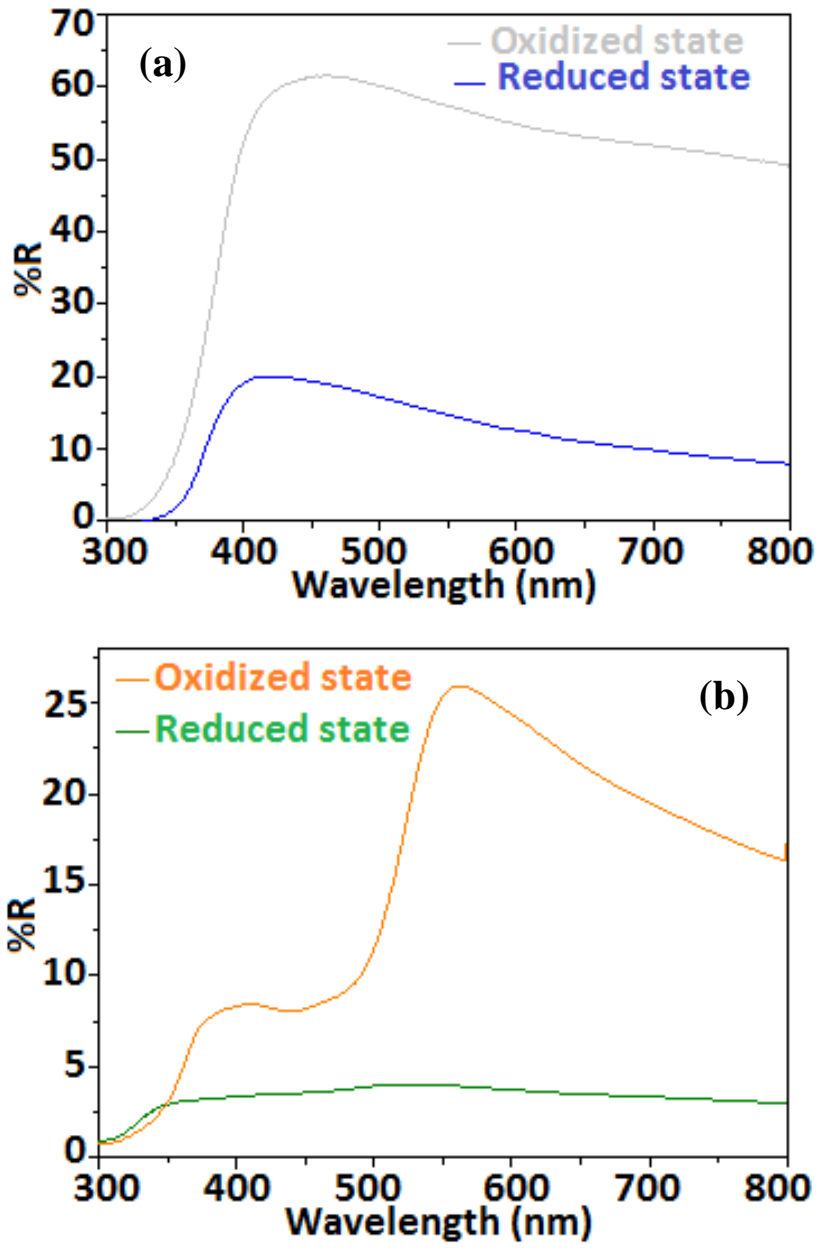

FIGURE 9. In-situ diffuse reflectance spectra of $\mathrm{Li}_{x}\left[\mathrm{Nb}_{2} \mathrm{O}_{5}\right.$ +PEDOT:PSS]/electrolyte/[ $\mathrm{V}_{2} \mathrm{O}_{5}+$ PEDOT:PSS] device at $-1 \mathrm{~V}$ for $30 \mathrm{~s}$ and $1 \mathrm{~V}$ for $30 \mathrm{~s}$ (a) face based niobium and (b) face based vanadium.

\section{Conclusion}

In summary, hexagonal nano- $\mathrm{Nb}_{2} \mathrm{O}_{5}$ was synthesized by facile and low-cost method, namely the polyol process. $\mathrm{Nb}_{2} \mathrm{O}_{5}$ electrochromic thin films were successfully deposited on ITO substrate at room temperature by Dip-Coating. Homogenous $\mathrm{Nb}_{2} \mathrm{O}_{5}$ films show nice electrochromic properties switching reversibly from white to blue color when cycled in lithium based ionic liquid electrolyte. Improvement of the electrochromic properties of $\mathrm{Nb}_{2} \mathrm{O}_{5}$ was achieved by mixing with PEDOT-PSS prior to the fabrication of a novel double-sided device built from $\quad \mathrm{Li}_{\mathrm{x}}\left[\mathrm{Nb}_{2} \mathrm{O}_{5}+\mathrm{PEDOT}\right.$ :PSS]/ electrolyte/[ $\left.\mathrm{V}_{2} \mathrm{O}_{5}+\mathrm{PEDOT}: \mathrm{PSS}\right]$ assembly. This double-sided electrochromic device exhibited nice optical contrast and fast color switching opening applications in the decorative field for instance. 


\section{ASSOCIATED CONTENT}

\section{Supporting Information}

The Supporting Information is available free of charge on the ACS Publications website at DOI:

Detailed description of the Full-pattern matching using isotropic peak profile function of the niobium pentoxide powders synthesized by polyol process and the unit-cells parameters and $\mathrm{R}$ reliability factors extracted from the pattern matching refinement of $\mathrm{Nb}_{2} \mathrm{O}_{5}$ powders annealed at $500{ }^{\circ} \mathrm{C}$ under air for $2 \mathrm{~h}$. A Detailed description of all the experimental procedures to prepare the two hybrids films prior to their assembly in a double-sided device.

\section{AUTHOR INFORMATION \\ Corresponding Author \\ E-mail: aline.rougier@icmcb.cnrs.fr. ORCID \\ Issam Mjejri: 0000-0001-5313-3198 \\ Aline Rougier: 0000-0002-1340-734X \\ AUTHOR CONTRIBUTIONS}

The manuscript was written through contributions of all authors.

The authors declare no competing financial interest.

\section{ACKNOWLEDGMENTS}

The authors thank Marion Gayot (CNRS, Université de Bordeaux, PLACAMAT UMS 3626) for the TEM images.

\section{ABBREVIATIONS}

EC, electrochromic

ECD, electrochromic device

CE, coloration efficiency

$\Delta \mathrm{E}^{*}$, optical contrast

(LiTFSI), lithium trifluoromethanesulfonimide.

(EMITFSI), 1-ethyl-3-methylimidazolium bis (trifluoromethanesulfonyl) imide.

PEDOT:PSS, poly(ethylene-3,4-dioxythiophene): poly (styrenesulfonicacid)).

\section{REFERENCES}

(1) Yang, Y.; Kim, D.; Schmuki, P. Lithium-ion Intercalation and Electrochromism in Ordered $\mathrm{V}_{2} \mathrm{O}_{5}$ Nanoporous Layers. Electrochem. Commun. 2011, 13, 1198-1201.

(2) Qu, H.; Zhang, X.; Pan, L.; Gao, Z.; Ma, L.; Zhao, J.; Li, Y. One-pot Preparation of Crystalline-Amorphous Double-Layer Structured $\mathrm{WO}_{3}$ Films and their Electrochromic Properties. Electrochim. Acta, 2014, 148, 46-52.

(3) Mjejri, I.; Manceriu, L. M.; Gaudon, M.; Rougier, A.; Sediri, F. Nano-Vanadium Pentoxide Films for Electrochromic Displays. Solid State Ionics 2016, 292, 8-14.

(4) Granqvist, C. G. Handbook of Inorganic Electrochromic Materials, 1995.
(5) Beaujuge, P. M.; Ellinger, S.; Reynolds, J.R. The DonorAcceptor Approach Allows a Black-to-Transmissive Switching Polymeric Electrochrome. Nat. Mater. 2008, 7, 795.

(6) Ding, Y.; Invernale, M. A.; Sotzing, G. A. Conductivity Trends of PEDOT-PSS Impregnated Fabric and the Effect of Conductivity on Electrochromic Textile. ACS Appl. Mater. Interfaces, 2010, 2, 1588-1593.

(7) Arvizu, M. A.; Niklasson, G. A.; Granqvist, C. G. Electrochromic $\mathrm{W}_{1-\mathrm{x}-\mathrm{y}} \mathrm{Ti}_{\mathrm{x}} \mathrm{Mo}_{\mathrm{y}} \mathrm{O}_{3}$ Thin Films Made by Sputter Deposition: Large Optical Modulation, Good Cycling Durability, and Approximate Color Neutrality. Chem. Mater. 2017, 29, 22462253.

(8) Gesheva, K.; Ivanova, T.; Popkirov, G.; Hamelmann, F. Optoelectronic Properties of CVD $\mathrm{MoO}_{3}$ and $\mathrm{MoO}_{3}-\mathrm{WO}_{3}$ Filmsand Their Applications in Electrochromic cells. J. Optoelect. Adv. Mater.2005, 7, 169-175.

(9) Reichman, A.J. Bard, J. Electrochem. Soc. 1980, 127(1) 241-242.

(10) Zhang, C.; Maloney, R.; Lukatskaya, M. R.; Beidaghi, M.; Dyatkin, B.; Perre, E.; Long, D.; Qiao, W.; Dunn, B.;

Gogotsi, Y. Synthesis and Electrochemical Eroperties of Niobium Pentoxide Deposited on Layered Carbide-Derived Carbon. J. Power Sources 2015, 274, 121-129.

(11) Pawlicka, A.; Atik M.; Aegerter, M.A. Synthesis of Multicolor $\mathrm{Nb}_{2} \mathrm{O}_{5}$ Coatings for Electrochromic Devices. Thin Solid Films 1997, 301, 236-241.

(12) Dash, J.K.; Chen, L.; Topka, M.R.; Dinolfo, P.H.; Zhang, L.H.; Kisslinger, K.; Lu T.-M.; and Wang, G.-C. A Simple Growth Method for $\mathrm{Nb}_{2} \mathrm{O}_{5}$ Films and their Optical Properties. RSC Adv., 2015, 5, 36129.

(13) Viet, A.L.; Reddy, M.V.; Jose, R.; Chowdari, B.V.R.; and Ramakrishna, S. Nanostructured $\mathrm{Nb}_{2} \mathrm{O}_{5}$ Polymorphs by Electrospinning for Rechargeable Lithium Batteries. J. Phys. Chem. C 2010, 114, 664-671.

(14) Rani, R.A.; Zoolfakar, A.S.; O'Mullane, A.P.; Austin, M.W.; Zadeh. K.K. Thin Films and Nanostructures of Niobium Pentoxide: Fundamental Properties, Synthesis Methods and Applications. J. Mater. Chem. A, 2014, 2, 15683.

(15) He, J.; Hu, Y.; Wang, Z.; Lu, W.; Yang, S.; Wu, G.; Wang, Y.; Wang, S.; Gu H.; and Wang J. Hydrothermal Growth and Optical Properties of $\mathrm{Nb}_{2} \mathrm{O}_{5}$ Nanorod Arrays. J. Mater. Chem. C, 2014, 2, 8185

(16) Dong, H.; Chen, Y.-C.; Feldmann, C. Polyol Synthesis of Nanoparticles: Status and Options Regarding Metals, Oxides, Chalcogenides, and Non-Metal Elements, green Chem., 2015, 17, 4107.

(17) L. Poul, S. Ammar, N. Jouini, F. Fievet, F. Villain, Journal of Sol-Gel Science and Technology 26, 261-265, 2003. (18) Feldmann; C. Polyol-Mediated Synthesis of Nanoscale Functional Materials. Adv. Funct. Mater. 2003,13.

(18) Mjejri, I.; Rougier, A.; Gaudon, M. Low-Cost and Facile Synthesis of the Vanadium Oxides $\mathrm{V}_{2} \mathrm{O}_{3}, \mathrm{VO}_{2}$, and $\mathrm{V}_{2} \mathrm{O}_{5}$ and Their Magnetic, Thermochromic and Electrochromic Properties. Inorg. Chem. 2017, 56, 1734-1741.

(20) Romero, R.; Dalchiele, E.A.; Martín, F.; Leinen, D.; Barrado J.R.R. Electrochromic Behaviour of $\mathrm{Nb}_{2} \mathrm{O}_{5}$ Thin Films with Different Morphologies Obtained by Spray Pyrolysis. Solar Energy Materials and Solar Cells. 2009, 93, 222-229

(21) Maruyama, T.; Arai, S. Electrochromic Properties of Niobium Oxide Thin Films Prepared by Radio-Frequency Magnetron Sputtering Method. Appl. Phys. Lett. 1993, 63, 869. 
(22) Weibin, Z.; Weidong, W.; Xueming, W.; Xinlu, C.; Dawei, Y.; Changle, S.; Liping, P.; Yuying, W.; Li, B. Surf. Interface Anal., 2013, 45, 1206-1210.

(23) Granqvist, C.G. Solid State Ionics 1992, 53, 479.

(24) Rosario, A.V.; Pereira, E.C. Optimisation of the Electrochromic Properties of $\mathrm{Nb}_{2} \mathrm{O}_{5}$ Thin Films Produced by Sol-Gel Route Using Factorial Design. Sol. Ener. Mater. Solar Cells, 2002, 71, 41-50.

(25) Mjejri, I.; Doherty, C. M.; Martinez, M. R.; Drisko, G.L.; Rougier, A. Double Sided Electrochromic Device based on Metal-Organic Frameworks. ACS Appl. Mater. Interfaces 2017, 9, 39930.

(26) Roy, S.; Mishra, S.; Yogi, P.; Saxena, S. K.; Mishra, V.; Sagdeo, P. R.; Kumar, R. Polypyrrole-Vanadium Oxide NaNocomposite: Polymer Dominates Crystallanity and Oxide Dominates Conductivity. Applied Physics A (2018) 124:53.

(27) Mishra, S.; Lambora, S.; Yogi, P.; Sagdeo, P.R. Kumar, R. Organic Nanostructures on Inorganic Ones: An Efficient Electrochromic Display by Design. ACS Appl. Nano Mater. 2018 1(7), 3715-3723.

(28) Ling, H.; Liu, L.; Lee, P.S.; Mandler, D.; Lu, X. Layerby-Layer Assembly of PEDOT:PSS and $\mathrm{O}_{3}$ Nanoparticles: Enhanced Electrochromic Coloration Efficiency and Mechanism Studies by Scanning Electrochemical Microscopy, Electrochim. Acta 2015, 174, 57-65.

(29) Kim, K.K.H.; Choi, D.; Lee, C. S. Evaluation of a Reliable Electrochromic Device based on PEDOT:PSS-TiO ${ }_{2}$ Heterostructure Fabricated at Low Temperature, Ionics 2017, 23.

(30) Lee, S. J.; Kim, H. P.; bin Mohd Yusoff, A. R.; Jang, J. Organic Photovoltaic With PEDOT:PSS and $\mathrm{V}_{2} \mathrm{O}_{5}$ Mixture as Hole Transport Layer. Sol. Energy Mater. Sol. Cells 2014, 120, 238-243.
(31) Alhummiany, H.; Rafique, S.; Sulaiman, K. XPS Analysis of the Improved Operational Stability of Organic Solar Cells Using a $\mathrm{V}_{2} \mathrm{O}_{5}$ and PEDOT:PSS Composite Layer: Effect of Varied Atmospheric Conditions, J. Phys. Chem. C 2017, 121, 7649-7658.

(32) Mishra, S.; Yogi, P.; Sagdeo, P. R.; Kumar, R. $\mathrm{TiO}_{2}-\mathrm{Co}_{3} \mathrm{O}_{4}$ Core-Shell Nanorods: Bifunctional Role in Better Energy Storage and Electrochromism. ACS Appl. Energy Mater. 2018, 1, 790-798.

(33) Zhang, S.; Ran, C.; Chen, S.; Gu, Y.; Jiang, M.; Hu, F.; Yan, B. Enhanced Electrochromic Performances of Polyaniline-Coated Rod-Like ATO/TiO ${ }_{2}$ Nanocomposites. J. The Electrochemical Society, 2017, 164 H1021-H1027 (2017).

(34) Bueno, P.R.; Avellaneda, C.O.; Faria, R.C.; Bulhoes, L.O.S. Electrochromic Properties of Undoped and Lithium Doped $\mathrm{Nb}_{2} \mathrm{O}_{5}$ Films Prepared by the Sol-Gel Method. Electrochim. Acta, 2001, 46, 2113-2118.

(35) Mujawar, S.H.; Inamdar, A.I.; Patil, S.B.; Patil, P.S. Electrochromic Properties of Spray-Deposited Niobium Oxide Thin Films. Solid State Ionics 2006, 177, 3333-3338.

(36) Liu, Y.; Lv, Y.; Tang, Z.; He, L.; Liu, X. Highly Stable and Flexible ITO-Free Electrochromic Films with Bi- Functional Stacked $\mathrm{MoO}_{3} / \mathrm{Ag} / \mathrm{MoO}_{3}$ Structures. Electrochim. Acta 2016, 189, 184-189.

(37) Coskun, O.D.; Demirel, S.; Atak, G. The Effects of Heat Treatment on Optical, Structural, Electrochromic and Bonding Properties of $\mathrm{Nb}_{2} \mathrm{O}_{5}$ Thin Films. J. Alloys Compds 2015, 648, 994-1004. 
TOC

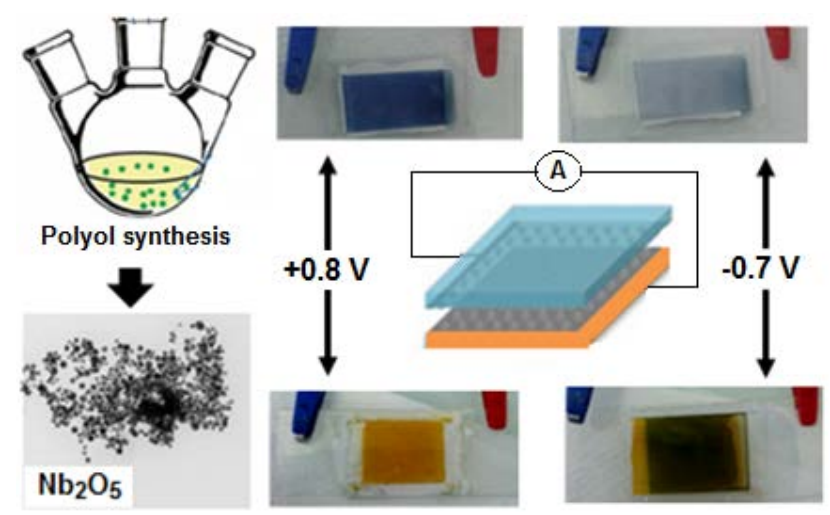

